\title{
KONSEPSI PERJANJIAN PENGIKATAN JUAL BELI RUMAH SUSUN MILIK SEBAGAI SEBUAH PANJER
}

\section{Sekhar Chandra Pawana1,}

1Fakultas Hukum Universitas Atma Jaya Yogyakarta, E-mail: schandrapawana@gmail.com

\begin{tabular}{l}
\hline Info Artikel \\
\hline Masuk: \\
Diterima : \\
Terbit : \\
Keywords : \\
Panjer, Adatrecht,, Apartement \\
\\
\\
Kata kunci: \\
Panjer, Hukum Adat, Rumah \\
Susun Milik \\
Corresponding Author: \\
Sekhar Chandra Pawana, E- \\
mail: schandrapawana@gmail.com \\
DOI: \\
Xxxxxxx
\end{tabular}

\begin{tabular}{l}
\hline Abstract \\
This research discusses on conception of the binding agreement \\
on the sale and purchase of apartment flats as a panjer in the \\
perspective of adat law and act of flat. The issue of this paper is \\
how is the conception of the binding agreement to buy and sell \\
the apartment as a panjer. This paper was conducted under the \\
basis of normative method with statute approach and conceptual \\
approach as secondary data were obtained from the literature \\
related with the topic. The Agreement on Binding of Sale and \\
Purchase can be interpreted in two perspectives. Bonding \\
Agreement Buying and selling can be said as a panjer if it does \\
not regulate the existence of a down payment which reduces the \\
selling price. \\
Abstrak \\
\hline Tulisan ini adalah penelitian yang membahas tentang konsepsi \\
perjanjian pengikatan jual beli rumah susun milik sebagai \\
sebuah panjer dalam perspektif hukum adat dan perundang- \\
undangan. Rumusan masalah yang dikemukakan adalah \\
bagaimana konsepsi perjanjian pengikatan jual beli rumah susun \\
milik sebagai sebuah panjer. Metode yang digunakan adalah \\
metode normatif dengan pendekatan peraturan perundang- \\
undangan dan pendekatan konseptual. Data yang digunakan \\
adalah data sekunder. Perjanjian Pengikatan Jual Beli dapat \\
dimaknai secara dua perspektif. Perjanjian Pengikatan Jual beli \\
dapat dikatan sebagai panjer apabila tidak mengatur tentang \\
adanya uang muka yang mengurangi harga jual.
\end{tabular}

\section{Pendahuluan}

Manusia adalah makluk sosial yang senantiasa berinterkasi dengan manusia lainnya. Interaksi sosial ini dilakukan dalam rangka memenuhi kebutuhan hidupnya. Interaksi sosial ini sebagai bentuk sarana memenuhi kebutuhan hidup. Salah satu kebutuhan hidup yang terutama adalah keberadaan tempat tinggal. Kebutuhan akan tempat tinggal yang bertambah tidak sebanding dengan keberadaan tanah yang sifatnya tetap. Permintaan terhadap tanah sebagai tempat manusia untuk membangun rumahnya tinggi menyebakan lahan semakin berkurang. Sebagai makluk yang dikarunai cipta rasa dan karsa, manusia berkembang seiring dengan perkembangan zaman. Perkembangan ini menimbulkan suatu pemikiran untuk membangun tempat tinggal secara vertikal. Pembangunan Rumah Susun merupakan sebuah solusi pemenuhan akan tempat tinggal bagi setiap manusia. Pada prakteknya proses jual beli atas rumah susun sering didahului proses pembuatan perjanjian pengikatan jual beli (PPJB) baik itu dibawah 
tangan maupun dihadapan notaris. Pembuatan perjanjian pengikatan jual beli dilakukan oleh karena adanya beberapa persyaratan untuk dilakukan pembuatan Akta Jual Beli belum dapat terpenuhi. Secara hukum pelaksanaan PPJB dibuat dalam bentuk perjanjian baku sehingga seringkali memiliki perbedaan isi dan redaksional, namun secara umum memiliki substansi yang sama. ${ }^{1}$ Dari pihak pembeli, pembeli belum dapat memenuhi dan melunasi pembayaran atas obyek jual beli. Dari pihak penjual obyek atas jual beli, sangat besar dimungkinkan belum ada atau obyek belum selesai terbangun. Keadaan dimana obyek belum selesai terbangun mengakibatkan belum ada sertipikat yang dapat dijadikan alat bukti kepemilikan yang sah untuk dapat disertakan saat dibuatnya akta jual beli. Dalam hukum perutangan adat, dikenal juga sebuah tanda pengikat yang dikenal dengan istilah panjer. Oleh karena PPJB merupakan perjanjian yang berisi atas janji-janji yang akan datang, perlu dikaji bagaimana konsepsi panjer dalam perjanjian pengikatan jual beli rumah susun milik.

\section{Metode Penelitian}

Metode yang digunakan dalam penulisan ini adalah metode penelitian hukum normatif, yang dilakukan dengan menggunakan data sekunder sebagai sumber data. Data sekunder terdiri dari bahan hukum primer dan bahan hukum sekunder. Pendekatan yang dilakukan adalah pendekatan perundang-undangan (statute approach) dan pendekatan konseptual (conceptual approach), artinya bahwa dasar menganalisis didasarkan pada peraturan perundang-undangan dan konsep-konsep yang ada pada bidang hukum adat serta terkait rumah susun. Teknik pengumpulan bahan hukum dengan metode kepustakaan, semua bahan-bahan dikumpulkan kemudian dibuatkan suatu catatan tentang hal-hal yang penting dalam penelitian ini, setelah bahan-bahan hukum yang diperoleh dianalisis secara deskriptif analisis.

\section{Hasil Dan Pembahasan}

\subsection{Proses Jual Beli Rumah Susun dengan Sistem Pre Project Selling}

Jual beli bagi manusia sudah merupakan bagian dari aktivitas keseharian untuk memenuhi kebutuhan hidup sehari-hari. Bagi dunia usaha jual beli dilakukan terutama untuk menjual hasil produksi atau membeli bahan baku dan bahan lainnya yang akan digunakan dalam proses produksi yang telah direncanakan sebelumnya termasuk di bidang properti. Penjual hasil produksi pembangunan bidang properti seperti penjualan perumahan, gedung atau hunian yang berbentuk rumah susun yang dikenal istilah apartemen, condominium atau flat baik sebelum bangunan terbangun maupun setelah bangunan sudah terbangun. ${ }^{2}$ Jual beli adalah sebuah perjanjian yang mana jual beli dianggap telah terjadi setelah para pihak mencapai sepakatan mengenai

\footnotetext{
${ }^{1}$ Brahmanta, A. G. A., \& Sarjana, I. M. (2016). Perlindungan Hukum Bagi Konsumen dalam Perjanjian Baku Jual Beli Perumahan dengan Pihak Pengembang di Bali. Acta Comitas: Jurnal Hukum Kenotariatan, hlm.217.

2 Urip Santoso, 2010, Pendaftaran Dan Peralihan Hak Atas Tanah, Kencana Prenada Media, Jakarta, hlm.77
} 
harga dan barangnya, sebagaimana diatur dalam Pasal 1457 KUPHPer jo Pasal 1458 KUHPer.

Rumah susun adalah bagunan gedung yang bertingkat yang dibangun dalam suatu lingkungan, yang terbagi dalam bagian-bagian yang distrukturkan secara fungsional dalm arah horizontal maupun vertikal dan merupakan Satuan satuan yang masing-masing dapat dimiliki dan digunakan secara terpisah, terutama untuk tempat hunian, yang dilengkapi dengan bagian bersama, benda bersama dan tanah bersama. Satuan rumah susun yang tujuan peruntukan utamanya digunakan secara terpisah sebagai tempat hunian, yang mempunyai secara terhubung ke jalan umum. Istilah yang memberikan pengertian hukum bagi bangunan gedung bertingkat yang senatiasa memberikan sistem pemilikan perseorangan dan hak bersama, yang penggunaanya untuk hunian secara mandiri ataupun secara terpadu sebagai suatu kesatuan suatu pembangunan ${ }^{3}$.

Ada beberapa istilah yang biasa dipakai untuk menggantikan rumah susun,diantaranya adalah condominium dan apartemen, di negara barat seperti Amerika Serikat rumah susun ini biasa disebut apartment, tetapi di Belanda biasa disebut flat. Mereka umumnya menggunakan istilah yang sama, baik rumah susun yang dihuni oleh lapisan masyarakat kelas atas, menengah maupun bawah. Akan tetapi, ada kecenderungan di Indonesia istilah rumah susun digunakan oleh penghuni lapisan masyarakat bawah dengan sarana dan perlengkapan rumah yang sederhana ${ }^{4}$.

Berdasarkan ketentuan Pasal 1 angka 1 Undang-Undang Nomor 20 Tahun 2011 tentang Rumah Susun, dinyatakan bahwa yang dimaksud dengan Rumah Susun adalah:

"Bangunan gedung bertingkat yang dibangun dalam suatu lingkungan, yang terbagi dalam bagian-bagian yang distrukturkan secara fungsional dalam arah horisontal dan vertikal dan merupakan satuansatuan yang masing-masing dapat dimiliki dan dihuni secara terpisah, terutama untuk tempat hunian, yang dilengkapi dengan bagian bersama, benda bersama dan tanah bersama".

Rumah Susun yang dimaksud dalam Undang-undang tentang, memberikan istilah bagi pengertian secara hukum sebuah rumah susun. Secara awam orang membedakan apa itu apartemen, condotel dan rumah susun. Secara terminologi konsep hukum leksikal bangunan gedung bertingkat yang senantiasa mengandung sistem pemilikan perseorangan dan hak bersama yang penggunaannya untuk hunian atau bukan hunian secara mandiri atau terpadu sebagai satu kesatuan sistem pembangunan. Berdasarkan ketentuan Pasal 1

\footnotetext{
${ }^{3}$ Kasman Siburian, 2013, Tinjauan Yuridis Terhadap Status Keberadaan Rumah Susun Berdasarkan Uu. No 20 Tahun 2011 Tentang Rumah Susun ; Jurnal Universitas Nomensen Sumatera Utara. ${ }^{4}$ Adrian Sutedi, 2010. Hukum Rumah Susun dan Apartemen,. Jakarta:Sinar Grafika., hlm. 156
} 
angka 3 Undang-Undang Nomor 20 Tahun 2011 tentang Rumah Susun, dinyatakan bahwa:

"Satuan Rumah Susun adalah unit rumah susun yang tujuan peruntukan utamanya digunakan secara terpisah sebagai tempat hunian, yang mempunyai sarana penghubung ke jalan umum".

Hubungan antara satuan-satuan rumah susun dengan benda bersama, bagian bersama dan tanah bersama dapat dilihat dari Nilai Perbandingan Proporsional. Angka inilah yang menunjukkan seberapa besarnya hak dan kewajiban dari seorang pemegang Hak Milik Atas Satuan Rumah Susun terhadap hak-hak bersamanya. Nilai Perbandingan Proporsional, ini dapat dihitung berdasarkan luas bangunan atau nilai rumah susun secara keseluruhan pada saat pertama kali memperhitungkan biaya pembangunan secara keseluruhan untuk menentukan harganya. ${ }^{42}$

Kebanyakan dalam praktek dilapangan proses jual beli Rumah Susun Milik dilakukan dengan sistem penjualan pre project selling yaitu jual beli yang dilakukan sebelum bangunan terbangun. Penjualan dengan cara ini dimaksudkan sebagai tes pasar atas produk yang dipasarkan yaitu unit-unit satuan rumah susun Dalam penjualan pre project selling ini tidak sedikit yang memesan atau melakukan pembelian sebelum unit Rumah Susun Milik telah selesai dibangun. Pembeli membayar sejumlah uang pengikat setelah menandatangani surat pemesanan sehingga untuk melanjutkan transaksi jual beli. Pelaku pembangunan sebagai pelaku usaha industri properti khususnya dalam hal pembangunan rumah susun kirannya harus memberikan informasi penting secara jelas dan akurat kepada pembeli mengenai produk yang ditawarkan seperti informasi jenis hak atas tanah, kondisi fisik bangunan dan harga jual. ${ }^{5}$ Rumah susun dapat diperoleh selain melalui jual beli, pemindahan hak dapat terjadi seperti tukar-menukar dan hibah. Penguasaan terhadap satuan unit rumah susun pada rumah susun komersial dapat dilakukan dengan cara dimiliki atau disewa. ${ }^{6}$

Dalam Undang-Undang Nomor 20 Tahun 2011 tentang Rumah Susun sebagai peraturan tertinggi yang menaungi pelaksanaan pembangunan dan penjualan rumah susun di Indonesia, kebutuhan setiap orang, dan partisipasi masyarakat serta tanggung jawab dan kewajiban negara dalam penyelenggaraan rumah susun. Transaksi jual beli rumah susun secara normatif berdasarkan Pasal 42 Undang-Undang Nomor 20 Tahun 2011 tentang Rumah Susun, diawali dengan penawaran yang dilakukan oleh marketing. Penawaran yang telah diterima dan disepakati oleh pembeli, kemudian akan dilakukan indent atau pemesanan yang ditulis dalam surat pemesanan oleh

42 Komar Andasasmita, Hukum Apartemen, Ikatan Notaris Indonesia Komisariat Jabar, Bandung, 1983, hlm.22.

5 Gunawan Widjaja dan Ahmad Yani, 2001, Hukum tentang Perlindungan Konsumen, PT Gramedia Pustaka Utama, Jakarta, hlm. 30.

6 Pasal 45 UU No 20 Tahun 2011 tentang Rumah Susun 
pembeli. Jika term and condition dalam surat pemesanan sudah dipenuhi maka kedua belah pihak akan membuat suatu perjanjian pengikatan jual beli yang berisi mengenai hak-hak dan kewajiban keduanya yang dituangkan dalam perjanjian pengikatan jual beli (PPJB) satuan rumah susun. Pelaku pembangunan kemudian harus menyiapkan akta jual beli kemudian bersamasama pembeli menandatanganinya dihadapan notaris. ${ }^{7}$ Dikeluarkannya Undang-Undang Nomor 20 Tahun 2011 tentang Rumah Susun maka sebelum pembeli mendapatkan kepastian hukum dalam memperoleh sertipikat hak milik rumah susun, maka pelaku pembangunan harus membuat klausula pertelaan terlebih dahulu sebelum bangunan selesai, bagi pelaku pembangunan ini sangat menyulitkan/merugikan. Bagi sisi pembeli akan memberikan suatu kepastian hukum.

Proses pemasaran dan jual beli rumah susun saat bangunan belum jadi, telah diatur dalam Pasal 42, Pasal 43 dan Pasal 44 Undang-Undang Nomor 20 Tahun 2011 tentang Rumah Susun (UU Rusun). Pasal 42 UU Rusun diatur bahwa pemasaran dapat dilakukan sebelum pembangunan rumah susun dilaksanakan. Pasal 43 ayat (3) diatur bahwa ketika pemasaran dilakukan sebelum pembangunan rumah susun segala sesuatu yang dijanjikan oleh pelaku pembangunan dan/atau agen pemasaran mengikat sebagai perjanjian pengikatan jual beli (PPJB) bagi para pihak. Pasal 43 ayat (2) Perjanjian Pengikatan Jual Beli (PPJB) dilakukan setelah memenuhi persyaratan kepastian atas : 8

1. Status Kepemilikan Tanah;

2. Kepemilikan IMB;

3. Ketersediaan Prasarana, Sarana, Dan Utilitas Umum;

4. Keterbangunan Paling Sedikit 20\% (Dua Puluh Persen); dan

5. Hal Yang Diperjanjikan

Pasal 43 Ayat (2) diatur bahwa proses jual beli unit Satuan Rumah Susun (Sarusun) sebelum pembangunan rumah susun selesai, dapat dilakukan melalui Perjanjian Pengikatan Jual Beli (PPJB) yang dibuat di hadapan notaris.

Proses pembelian unit satuan rumah susun Apartemen juga diawali dengan Surat Pemesana lalu dibuat Perjanjian Pengikatan Jual Beli (PPJB) baik itu di hadapan notaris maupun bawah tangan9. PPJB merupakan perjanjian pendahuluan dalam jual beli unit sarusun antara pihak penjual dan pihak pembeli, dikarenakan adanya halangan-halangan sebelum dilaksanakan perjanjian pokok. ${ }^{10}$. Halangan- halangan tersebut antara lain adanya syarat yang

7 Proses ini sesuai dengan Keputusan Menteri Negara Perumahan Rakyat No 11/KPTS/1994.

8 Lihat Pasal 42,43 Undang-undnag Nomor 21 Tahun 2011 tentang Rumah Susun

9 Proses ini ditemukan pada saat melihat langsung dan mewancara penjual salah satu apartemen di Yogyakarta

10 Pasal 2 ayat (1) dan (2) Peraturan Pemerintah No. 37 Tahun 1998 tentang Peraturan Jabatan Pejabat Pembuat Akta Tanah 
belum terpenuhi, seperti obyek jual beli yang diperjanjikan belum selesai dibangun, sertipikat yang masih dalam proses, proses pendaftaran peralihan hak maupun sedang proses pemecahan/pertelaan di Kantor Pertanahan, serta pajak yang belum lunas, dan/atau pembayaran yang belum lunas. ${ }^{11}$

Keputusan Menteri Perumahan Rakyat No 11/KPTS/1994 tentang Pedoman Perikatan Jual Beli Satuan Rumah Susun, diatur bahwa Perjanjian Pengikatan Jual Beli (PPJB) sekurangnya memuat luas satuan rumah susun, harga jual satuan rumah susun, dan ketentuan pembayaran uang muka, spesifikasi bangunan, dan tanggal selesainya pembangunan. Unsur pokok dalam perjanjian jual beli adalah barang dan harga. Penjual dan pembeli saat terjadi harus ada kata sepakat tentang harga dan barang yang menjadi objek jual beli sebab salah satu ciri jual beli ialah terang dan tunai12. Barang dalam jual beli satuan rumah susun pre project selling adalah unit satuan rumah susun.

\subsection{Kedudukan Perjanjian Pengikatan Jual Beli sebagai Tanda Pengikat dalam Hukum Adat}

Hubungan hukum dalam perjanjian, bukan suatu hubungan yang bisa timbul dengan sendirinya seperti yang terdapat dalam harta benda kekeluargaan. Dalam hubungan hukum kekayaan keluarga, dengan sendirinya timbul hubungan hukum antara anak dengan kekayaan orang tuanya seperti yang diatur dalam hukum waris. Lain halnya dalam perjanjian, hubungan hukum antara pihak yang satu dengan pihak yang lain tidak bisa timbul dengan sendirinya. Hubungan tersebut tercipta oleh karena adanya "tindakan hukum". Tindakan hukum yang dilakukan oleh pihak-pihaklah yang menimbulkan hubungan hukum perjanjian, sehingga terhadap satu pihak diberi hak oleh pihak yang lain untuk memperoleh prestasi. Sedangkan pihak yang lain itupun menyediakan diri dibebani dengan kewajiban untuk menunaikan prestasi.

Prestasi ini adalah "objek" atau "voorwerp" dari perjanjian/verbintenis. Tanpa prestasi, hubungan hukum yang dilakukan berdasarkan tindakan hukum sama sekali tidak mempunyai arti apa-apa bagi hukum perjanjian. Pihak yang berhak atas prestasi mempunyai kedudukan sebagai "schuldeiser"atau "kreditur". Pihak yang wajib menunaikan prstasi berkedudukan sebagai "schuldenaar" atau "debitur". Objek atau "voorwerp" itu merupakan benda, namun hukum perjanjian hanya mengatur dan mempersalahkan hubungan benda/kekayaan yang menjadi objek perjanjian antara "pribadi tertentu". Pada umumnya hak yang lahir dari perjanjian itu hak yang bersifat relatif, artinya hak hak atas prestasi baru ada pada persoon tertentu, jika hal itu didasarkan pada hubungan hukum yang lahir atas perbuatan hukum. Namun, ada beberapa pengecualian tentang hal tersebut yaitu :

11 Pasal 2 ayat (1) dan (2) Peraturan Pemerintah No. 37 Tahun 1998 tentang Peraturan Jabatan Pejabat Pembuat Akta Tanah

12 Ridwan Khairandy, 2016, Perjanjian Jual Beli, Yogyakarta, UII Press, hlm.35 
a.

b.
Sekalipun tidak ada hubungan hukum yang mengikat antara dua orang tertentu (bepalde persoon), verbintenis bisa terjadi oleh suatu "keadaan/kenyataan tertentu".

Atau oleh karena suatu "kewajiban hukum dalam situasi yang nyata", dapat dikonkritisasi sebagai verbintenis. Sekalipun sebelumnya tidak ada hubungan hukum antara dua orang tertentu.

Mengacu pada Pasal 1457 KUH Perdata, perjanjian jual beli adalah suatu perjanjian dengan perjanjian itu pihak yang satu mengikatkan dirinya untuk menyerahkan hak milik atas barang dan pihak yang lain untuk membayar harga yang telah dijanjikan. Jual Beli Rumah Susun MIlik adalah proses pihak yang satu mengikatkan dirinya untuk menyerahkan hak milik atas barang yaitu Hak Milik unit satuan rumah susun atas Rumah Susun Milik dari pelaku pembangunan kepada pembeli. Pihak yang lain yaitu pembeli memiliki kewajiban untuk membayar harga yang telah dijanjikan. Dengan demikian kegiatan jual beli Rumah Susun Milik terdapat dua belah pihak yaitu pihak penjual maupun pembeli, yang menjadi unsur-unsur pokok (essentialia) perjanjian jual beli adalah barang dan harga yang bersifat terang dan tunai. Sebagai bangunan yang di "stratakan", artinya bahwa satuan unit apartemen maupun kondotel memiliki kepemilikan individu dan kepemilikan bersama, maka hak milik atas unit satuan rumah susun Rumah Susun Milik juga meliputi hak atas bagian bersama, benda bersama dan tanah bersama di lingkungan Rumah Susun Milik yang bersangkutan sesuai dengan Nilai Perbandingan Proporsional yang tercantum dalam Akta Pertelaan dan Sertipikat Hak Milik Atas Satuan Rumah Susun SHMSRS.

Perjanjian Pengikatan Jual Beli (PPJB) memiliki pengertian sebagai sebuah perjanjian pendahuluan, yang memuat janji-janji dari para pihak yang mengandung ketentuan-ketentuan jika syarat-syarat jual beli sudah terpenuhi. Perjanjian ini dilakukan oleh karena kondisi syarat-syarat dalam perjanjian pokok belum dipenuhi dalam hal ini adalah perjanjian jual beli, objeknya adalah unit stauan rumah susun. Perjanjian pengikatan jual beli lazim digunakan dalam transaski yang berkaitan dengan benda tetap. Benda tetap dalam Pasal 616 Kitab Undang-Undang Hukum Perdata (KUHPer) disebut dengan benda tidak bergerak. Pasal 616 Kitab Undang-Undang Hukum Perdata(KUHPer) mengatur bahwa penyerahan benda tidak bergerak terjadi melalui pengumuman akta yang bersangkutan dengan cara seperti ditentukan dalam pasal 620 KUHPer Juncto Pasal 19 Undang-Undang Nomor 5 Tahun 1960 tentang Peraturan Dasar PokokPokok Agraria (UUPA). Tindakan yang dilakukan antara lain dengan membukukan dalam register atau dalam masyarakat dikenal istilah pensertifikatan tanah. Tanah dan bangunan. Merupakan contoh benda tidak 
bergerak. Termasuk Unit Satuan Rumah Susun adalah benda tidak berderak atau benda tetap.

. Janji - janji tersebut harus dipenuhi oleh salah satu pihak atau para pihak sebelum dilakukan perjanjian pokok. Perjanjian Pengikatan Jual Beli (PPJB) adalah kesepakatan dari dua pihak untuk melaksanakan prestasi masing-masing di kemudian hari, yakni pelaksanaan jual beli di hadapan Pejabat Pembuat Akta Tanah (PPAT). Perjanjian itu sendiri merupakan sumber perikatan yang terpenting. ${ }^{13}$ Perjanjian Pengikatan Jual Beli (PPJB) dapat digolongkan sebagai Partij Akte, artinya dibuat menurut permintaan para pihak dengan mendasarkan data dan keterangan para pihak yang bisa dipertanggung jawabkan kebenarannya. Notaris hanya sebatas mengkomodir keinginan para pihak (pembeli dan penjual) dan menuangkannya ke dalam akta. ${ }^{14}$ Proses selanjutnya yaitu proses pembuatan Akta Jual Beli (AJB) yang harus dilakukan di hadapan PPAT maka diserahkan kembali kepada para pihak. ${ }^{15}$ Saat dua orang mengadakan suatu perjanjian, maka mereka bermaksud supaya antara mereka berlaku suatu perikatan hukum. Perjanjian pengikatan jual beli (PPJB) merupakan bentuk perikatan dengan ketentuan waktu. PPJB merupakan perjanjian jenis baru di luar Kitab Undang-Undang Hukum Perdata (KUHPerdata) yang menjadi dasar dari PPJB adalah perjanjian jual beli dimana terdapat syarat-syarat jual beli yang belum terpenuhi. Pengertian ketentuan waktu ialah suatu hal yang akan datang, meskipun mungkin belum dapat ditentukan kapan datangnya. Penyebab tersebut, mendasari langkah pengamanan kepentingan penjual dan pembeli dan kemungkinan terjadinya halhal yang tidak diinginkan misalnya terjadi ingkar janji dari para pihak. PPJB menjadi suatu pegangan atau pedoman dalam transaksi jual beli dengan sistem pre project selling.

Berdasarkan teori hukum, Perjanjian pengikatan jual beli (PPJB) merupakan hubungan hukum yang berada berada dalam lingkungan hukum diatur oleh undang-undang mengandung suatu hubungan hukum kekayaan atau harta benda antara dua orang atau lebih yang menimbulkan kekuatan hak pada suatu pihak untuk memperoleh prestasi dan sekaligus mewajibkan pada pihak lain untuk menunaikan prestasi. ${ }^{16}$ Dengan kata lain, PPJB seperti jembatan penghubung antara proses transaksi dari Surat Pemesanan dan proses Akta Jual Beli. Perjanjian Perikatan Jual Beli. Proes ini merupakan suatu tahap awal yang mendasari terjadinya jual beli Rumah Susun Milik. Pada dasarnya perjanjian jual beli identik dengan sebuah aktivitas bisnis. Terkait hubungannya dengan

${ }^{13}$ Hasil wawancara dengan Srihandiri Sasmita selaku Notaris dan PPAT di Yogyakarta

${ }^{14}$ Hasil wawancara dengan Srihandini Sasmita, Ibid,.

${ }^{15}$ Ibid

16 Supriyadi, Kedudukan Perjanjian Pengikatan Jual Beli Hak Atas Tanah Dalam Perspektif Hukum Pertanahan, Jurnal ARENA HUKUM Volume 9, Nomor 2, Agustus 2016, hlm 216 
kegiatan bisnis, perjanjian jual beli berfungsi untuk mengamankan transaksi. ${ }^{17}$ Dalam membuat suatu perjanjian, para pihak hendaknya senantiasa memperhatikan aspek hukum perdata yang membingkai aktivitas bisnis mereka. Perjanjian tersebut akan melindungi proses bisnis para pihak apabila perjanjian tersebut memenuhi syarat-syarat sahnya perjanjian. Apabila perjanjian tersebut ingin dilaksanakan oleh para pihak yang membuatnya dengan baik dan lancar, maka haruslah dibuat secara sah. Jika dibuat secara tidak sah, maka akan menimbulkan akibat hukum tersendiri dan akan menimbulkan sengketa bagi para pihak di kemudian hari. Begitu pula dalam hal jual beli rumah susun, tentu juga ada syarat-syarat yang harus diperhatikan agar membuat perjanjian jual beli tersebut dapat dikatakan sah.

Perjanjian Pengikatan Jual Beli (PPJB) dari sisi transaksi properti merupakan konsekuensi dari startegi pemasaran yang bersifat pre project selling, yakni penjualan yang dilakukan sebelum bangunan fisik apartemen atau rumah susun selesai dibangun. Langkah ini ditempuh lebih didasarkan pada pertimbangan ekonomi bagi pelaku pembangunan yaitu sarana melakukan test pasar terhadap produk yang dijualnya serta mendapatkan dana dari pembeli. Bagi pembeli ialah mendapatkan unit rumah susun dengan harga yang lebih rendah. Dalam melakukan transaksi properti seperti ini, setelah dilakukan pemesanan maka kedua belah pihak akan membuat suatu perjanjian yang berisi hak dan kewajiban bagi para pihak, kemudian dapat dituagkan dalam Akta Pengikatan Jual Beli. ${ }^{18}$ Berdasarkan fakta empiris tidak jarang pembeli harus terlebih dahulu mebayar uang tanda jadi baru kemudian diberikan PPJBnya. ${ }^{19}$

Asas konsesualisme perjanjian jual beli secara intrinsik diatur dalam pasal 1458 KUHPerdata. Ditegaskan dalam Pasal 1458 KUH-Perdata yang tertulis "Jual beli dianggap telah terjadi keduabelah pihak sewaktu mereka telah mencapai sepakat tentang barang dan harga meskipun barang itu belum diserahkan maupun harganya belum dibayàr". 20 Sesuai dengan asas "konsensualisme" yang menjiwai hukum perjanjian KUHPerdata perjanjian jual beli itu sudah dilahirkan pada detik tercapainya "kesepakatan" mengenai barang dan harga. Begitu kedua belah pihak sudah setuju tentang barang dan harga, maka lahirlah perjanjian jual beli yang sah di antara kedua belah pihak tersebut, perjanjian yang dibuat

17 Agus Yudha Hernoko, 2016, Asas Proporsionalitas Sebagai Landasan Pertukaran Hak Dan Kewajiban Para Pihak Dalam Kontrak Komersial Jurnal Hukum dan Peradilan, Volume 5 Nomor 3, November 2016, hlm 241

18 Maria S.W. Sumardjono, 2001,. Kebijakan Pertanahan Antara Regulasi dan Implentasi, Jakarta, Kompas, Hlm 161.

19 Yusuf Shofie, 2000, Perlindungan Hukum onsumen dan Instrumen - Insturmen Hukunnya,Bandun, Citra Aditya Bakti,. Hlm 98 Hal ini juga terlihat saat penulis melakukan wawancara dengan salah satu pembeli dalam proses jual beli apartemen student castle di yogyakarta dimana sebelum dibuatkan PPJB pembeli harus membayar uang muka terlebih dahulu.

20 Akhmad Budi Cahyono dan Surini Ahlan Sjarif, 2008, Mengenal Hukum Perdata, Jakarta, Gitama Jaya,. Hlm 133 
sebelumnya akan melahirkan suatu perikatan secara hukum yang akan mengikat kedua belah pihak. Sifat konsensual dari jual beli tersebut ditegaskan dalam Pasal 1458 KUHPerdata yang diatur bahwa jual beli dianggap sudah terjadi antara kedua belah pihak seketika setelah mereka mencapai sepakat tentang barang dan harga, meskipun barang itu belum diserahkan maupun harganya belum dibayar.

Pasal 1338 ayat (1) KUHPerdata diatur bahwa semua perjanjian yang dibuat secara sah, mengikat sebagai undang-undang bagi para pihak yang membuatnya. Asas yang kedua yang terkandung dalam pasal 1338 adalah asas pacta sunt servanda berdasarkan kalimat "berlaku sebagai udnag-undang bagi yang membuatnya". Hal ini berimplikasi adanya kekuatan hukum dari perjanjian yang dibuat oleh para pihak, yaitu dapat dipaksakannya prestasi yang sudah disepakati oleh para pihak. Prestasi tidak dijalankan oleh hukum dimungkinkan untuk menuntut kewajiban atas prestasi yang tecantum dalam perjanjian tersebut ${ }^{21}$. Upaya ini berupa tuntutan pelaksanaan perjanjian secara paksa dan ganti rugi apabila terjadi kerugian sebagai akibat tidak dilaksanakannya prestasi.

Sebuah keputusan mahkamah agung berupa Surat Edaran Mahkamah Agung (SEMA) Nomor 4 Tahun 2016 Bagian B tentang rumusan kamar perdata angka 7 diatur bahwa peralihan hak atas tanah yang berdasarkan Perjanjian Pengikatan Jual Beli (PPJB) secara hukum terjadi jika pemilik telah membayar lunas harga tanah serta menguasai obyek jual beli yang dilakukan dengan itikad baik. Adanya perjanjian pengikatan jual beli bukan berarti sebuah benda yang menjadi obyek perjanjian sudah beralih kepemilikannya. Peralihan atas benda tetap, mengikuti prosedur hukum formil bagaimana sebuah benda tetap dapat beralih kepemilikannya kepada pemilik yang baru. Dalam hal jual-beli maka, saat dibuat Akta Jual Beli dihadapan Pejabat Pembuat Akta Tanah (PPAT) telah terjadi jual beli dan sejak saat itu harus dilakukan langkah selanjutnya agar secara yuridis peralihan hak atas benda tetap sah terjadi.

Dalam SEMA Nomor 4 Tahun 2016 Bagian B tentang rumusan hukum kamar perdata angka 5 diatur mengenai pengertian pembeli beritikad baik sebagaimana tercantum dalam kesepakatan kamar perdata tanggal 9 Oktober 2014 pada huruf a disempurnakan. Seorang pembeli dikatakan berikitkad baik apabila melakukan hal-hal berikut :

a. Melakukan jual beli atas obyek tanah tersebut dengan tata cara atau prosedur dan dokumen yang sah sebagiamana telah ditentukan peraturan perundangundangan yang berlaku. Prosedur berdasarkan peraturan perundanganundnagan yang berlaku yaitu,

- Pembelian melakui pelelangan umum;

- Pembelian tanah dihadapan Pejabat Pembuat Akta Tanah sesuai dnegan ketentuan Peraturan Pemerintah Nomor 24 Tahun 1997.

${ }^{21}$ Munir Fuady, 2005, Pengantar Hukum Bisnis, Bandung, Citra Aditya Bakti,. Hlm 13 
- Selain terhadap tanah yang secara yuridis formal dimiliki individu. Kriteria pembeli memiliki itikad baik juga ada pada saat proses pembelian tanah milik adat atau yang belum terdaftar yang dilaksanakan menurut ketentuan hukum adat. jual beli ini dilakukan secara tunai terang artinya di hadapan atau diketahui Kepada Desa/Lurah steempat. Didahului dengan penelitian mengenai status tanah obyek jual beli dan berdasarkan penelitian tersebut menunjukkan bahwa tanah obyek jual beli adalah milik penjual.

- Pembelian dilakukan dengan harga yang layak

b. Melakukan kehati-hatian dengan meneliti hal-hal berkaitan dengan obyek tanah yang diperjanjikan antara lain :

- Penjual adalah orang yang berhak atau memiliki hak tas tanah yang menjadi obyek jual beli, sesuai dengan bukti kepemilikannya;

- Tanah atau obyek yang diperjual belikan tersbeut tidak dalam status disita;

- Tanah obyek yang diperjual belikan tidak dalam status jaminan atau berada dalam hak tanggungan;

- Terhadap tanah yang bersetifikat, telah memperoleh keterangan dari Badan Pertanahan Nasional dan riwayat hubungan hukum antara tanah tersebut dengan pemegang sertifikat.

Perjanjian jual beli menurut Pasal 1457 KUH Perdata adalah suatu perjanjian dengan perjanjian itu pihak yang satu mengikatkan dirinya untuk menyerahkan hak milik atas barang dan pihak yang lain untuk membayar harga yang telah dijanjikan. Pada tanggal 23 Juni 1995 Kementerian Negara Perumahan Rakyat telah menetapkan suatu peraturan tentang pedoman pengikatan jual beli rumah dengan Kepmenpera No. 9/KPTS/M/1995. Keputusan Menteri tersebut mengatur bagaimana hubungan bisnis antara pelaku usaha industri perumahan/pengembang dengan masyarakat sebagai konsumen. Bahwa adanya dua pihak yakni perusahaan pembangunan perumahan dan permukiman yang bertindak selaku penjual rumah atau produsen dan konsumen rumah yang bertindak selaku pembeli rumah yang disebut konsumen. Keputusan Menteri Perumahan No. 9 Tahun 1995 tentang pedoman pengikatan jual beli rumah memuat beberapa aturan antara penjual/pelaku pembangunan dengan pembeli/konsumen perumahan, yaitu :
a. Kewajiban penjual
b. Jaminan penjual
c. Kewajiban pembeli
d. Serah terima bangunan
e. Pemeliharaan bangunan
f. Penggunaan bangunan
g. Pengalihan hak
h. Ketentuan pembatalan pengikatan 
i. Akta jual beli

j. Penyelesaian perselisihan

Pada fakta empiris, pensertifikatan tanah ini sering lambat prosesnya, padahal pembeli merupakan pembeli yang beritikad baik. Dalam konteks ini perjanjian pengikatan jual beli muncul sebagai sebuah pengikat bagi para pihak yaitu pembeli dan penjual. Adanya janji-janji yang akan dilakukan diikat dalam Perjanjian Pengikatan Jual Beli ini. Termasuk didalamnya sebuah pembayaran dan kapan barang akan diserahkan. Arti penting pembuatan PPJB ini sebagai sebuah kontrak tertulis dalam praktik bisnis adalah untuk menjaminpertukaran kepentingan (hak dan kewajiban) berlangsung secara proprosional bagi para pihak, sehingga dengan demikian terjalin hubungan kontraktual yang adil dan saling menguntungkan. Bukan sebaliknya, merugikan salah satu pihak atau bahkan pada akhirnya justru merugikan para pihak yang berkontrak.

Soerjono Soekanto berpendapat dalam bukunya bahwa panjer itu cenderung diartikan sebagai sebuah tanda jadi, yang didalamnya terselip unsur saling percaya mempercayai antara para puhak. ${ }^{22}$ Menurut hukum adat, arti dari panjer adalah sebuah perwujudan dari itikad baik seseorang. Dalam hal salah satu pihak tidak menaati apa yang sudha disepakati maka panjer dianggap hilang, sedangkan apabila penerima panjer yang melalauikan kesepakatan maka penerima panjer wajib mengembalikan panjer itu dan ditambahkan lagi dengan membayar uang sebesar panjer yag diberikan, dengan kata lain penerima panjer yang melalaikan janjinya akan membayar uang panjer sebanyak dua kali lipat. Panjer muncul pada saat terjadi suatu tindakan tertentu yang mengakibat sebuah perikatan, dalam hal ini adalah jual beli. Pemberian ini memunculkan sebuah perikatan antara kedua belah pihak, yaitu pembeli dan penjual. Dapat dikatakan apabila pembeli tidak memberikan panjer kepada penjual, maka berakibat kedua belah pihak merasa dirinya tidak terikat pada kesepakatan yang telah dilakukan.

Berbicara soal uang muka, tidak ada ketentuan tersendiri yang mengaturnya. Pasal 1464 Kitab Undang-Undang Hukum Perdata (KUHPer) hanya mengatur mengenai uang pengikat. Pasal 1464 KUHPer dikatakan bahwa kondisi terjadi jual beli dengan memberi uang panjar, maka salah satu pihak tak dapat membatalkan pembelian itu dengan menyuruh memiliki atau mengembalikan uang panjarnya. Pasal ini mengandung makna tidak ada uang muka. Dalam Kamus Besar Bahasa Indonesia Uang Panjar disamakan dengan Down Payement atau Uang Muka. ${ }^{23}$

\section{Kesimpulan}

22 Soerjono Soekanto, 2008, Hukum Adat Indonesia, Raja Grafindo Persada Indonesia, hlm 89

${ }^{23}$ https://www.hukumonline.com/klinik/detail/ulasan/lt50e74bdfb18c3/bolehkah-menolakkembalikan-uang-panjar-jika-pembelian-batal 
Sebuah panjer merupakan wujud dari sifat dan corak dari hukum adat yang bersifat tunai, riil, dan nyata, maka kedudukan Perjanjian Pengikatan Jual Beli sebagai sebuah pengikat di awal transaksi jual beli mempunyai dua pespektif. Perjanjian Pengikatan Jual Beli (PPJB) Rumah Susun Milik dalam praktek sehari-hari dapat dimaknai sebagai sebuah panjer apabila dalam klausul tidak tercantum uang muka telah dibayarkan. Isi dari perjanjina yang dibuat hanya semacam pengikatan atas janji saja Perjanjian Pengikatan Jual Beli Rumah Susun Milik bukanlah sebuah panjer apabila isi dari PPJB terdapat uang muka yang mengurangi harga beli atas objek jual beli yaitu rumah susun milik.

\section{DAFTAR PUSTAKA}

\section{Buku}

Andasasmita, Komar,(1983), Hukum Apartemen, Ikatan Notaris Indonesia Komisariat Jabar, Bandung.

Cahyono, Akhmad Budi dan Surini Ahlan Sjarif, (2008), Mengenal Hukum Perdata, Jakarta, Gitama Jaya.

Fuady, Munir ,(2005), Pengantar Hukum Bisnis, Bandung, Citra Aditya Bakti

Khairandy Ridwan, (2016,), Perjanjian Jual Beli, Yogyakarta, UII Press.

Santoso, Urip, (2010), Pendaftaran Dan Peralihan Hak Atas Tanah, Jakarta, Kencana Prenada Media

Shofie,Yusuf,(2000), Perlindungan Hukum Konsumen dan Instrumen - Insturmen Hukunnya, Bandung, Citra Aditya Bakti.

Soekanto, Soerjono , (2008), Hukum Adat Indonesia, Jakarta, Raja Grafindo Persada Indonesia

Sumardjono, Maria S.W., (2001), Kebijakan Pertanahan Antara Regulasi dan Implentasi, Jakarta, Kompas.

Sutedi, Adrian, (2010), Hukum Rumah Susun dan Apartemen, Jakarta, Sinar Grafik

Widjaja, Gunawan dan Ahmad Yani, (2001), Hukum tentang Perlindungan Konsumen, Jakarta, PT Gramedia Pustaka Utama.

\section{Jurnal}

Brahmanta, A. G. A., \& Sarjana, I. M. (2016). Perlindungan Hukum Bagi Konsumen dalam Perjanjian Baku Jual Beli Perumahan dengan Pihak Pengembang di Bali. Acta Comitas: Jurnal Hukum Kenotariatan.

Hernoko, Agus Yudha, (2016), Asas Proporsionalitas Sebagai Landasan Pertukaran Hak Dan Kewajiban Para Pihak Dalam Kontrak Komersial Jurnal Hukum dan Peradilan, Volume 5 Nomor 3, November 2016.

Kasman, Siburian, (2013), Tinjauan Yuridis Terhadap Status Keberadaan Rumah Susun Berdasarkan Uu. No 20 Tahun 2011 Tentang Rumah Susun ; Jurnal Universitas Nomensen Sumatera Utara.

Supriyadi, (2016) Kedudukan Perjanjian Pengikatan Jual Beli Hak Atas Tanah Dalam Perspektif Website Hukum Pertanahan, Jurnal ARENA HUKUM Volume 9, Nomor 2, Agustus 2016.

https://www.hukumonline.com/klinik/detail/ulasan/lt50e74bdfb18c3/bolehkah-menolakkembalikan-uang-panjar-jika-pembelian-batal 


\section{Peraturan Perundang-undangan}

Undang-Undang Nomor 20 Tahun 2011 tentang Rumah Susun (Lembaran Negara Republik Indonesia Tahun 2011 Nomor 208, Tambahan Lembaran Negara Republik Indonesia nomor 5252).

Peraturan Pemerintah No. 37 Tahun 1998 tentang Peraturan Jabatan Pejabat Pembuat Akta Tanah

Keputusan Menteri Negara Perumahan Rakyat No 11/KPTS/1994. 